\title{
Selection of filamentous fungi for the biocontrol of Rhipicephalus (Boophilus) Microplus in tropical regions
}

\begin{abstract}
Rhipicephalusmicroplus is an ectoparasite that causes significant losses to livestock due to spoliation of cattle and the high cost of current control techniques. The control of this parasite is chemically accomplished, but the incorrect use of this method is causing resistance in this species. An alternative to control would be the use of fungi, as they do not need to be ingested by the host, being only necessary to have contact with the target such that it can grow and colonize. Thus, the present study aimed to isolate, identify and select efficient fungal strains in the biological control of Rhipicephalus microplus in tropical weather, such as found in Brazil. Soil and Brachiaria brizantha forage samplings were carried out for isolation, quantification and identification of fungal species. Engaged females of R. Microplus were collected for the bioassay of colonization rate, hatchability of eggs and production of mycotoxins. A total of $2 \times 10^{-3}$ $\mathrm{CFU} \mathrm{g}{ }^{-1}$ fungi were found and five genera were identified. Aspergillus spp. was the most frequent genus amidst the isolates obtained from both environments. The forage presented a greater amount of fungal colonies. $\mathrm{g}^{-1}$ when compared to the soil. We identified entomopathogenic, saprophytic, pathogenic and keratinophilic species with biotechnological potential as well as for use for biological control. Aspergillus was the most prevalent genus in both soil and forage of tropical regions. Elevated fungal variety was observed in the ecosystems we studied. Metarhizium anisopliae efficiently colonized the parasites in an $80 \%$ rate, and differed from other treatments $(p<0.01)$. These study open doors for investigations concerning the evaluation of other fungi colony counting's, forms of manipulation and other bioassays.
\end{abstract}

Keywords: dairy cattle, tick, biological control, in vitro tests, microbiology, rmicroplus, rhipicephalusmicroplus, aspergillus
Volume 5 Issue 2 - 2017

\author{
Jéssica Patrícia De Oliveira,' Bruno De \\ Sousa Pereira,' Marcus Vinícius Dias-Souza, ${ }^{2}$ \\ Emiliane Dos Santos Belo, ${ }^{3}$ Flávia Oliveira \\ Abrão Pessoa ${ }^{4}$ \\ 'Instituto Federal de Educação, SA \\ ${ }^{2}$ Departament of Microbiology, Universidade Federal de Minas \\ Gerais, SA \\ ${ }^{3}$ Federal Institute of Education, Science and Technology of \\ Goiano, SA \\ ${ }^{4}$ Instituto Federal Goiano-Campus Ceres, Escola De Veterinária \\ Da UFMG, SA
}

\begin{abstract}
Correspondence: Flávia Oliveira Abrão Pessoa, Instituto Federal Goiano-Campus Ceres, Escola De Veterinária Da UFMG, Caixa Postal 5I, Rodovia GO I54, Km 03, s/n, Zona Rural-Ceres-GO, 76.300 000, Goiás, SA, Tel +55 6233077100 Email flavia.abrao@ifgoiano.edu.br
\end{abstract}

Received: August 25, 2016 | Published: April 10, 2017

\section{Introduction}

Ticks are ectoparasites characterized mainly by blood feeding, independently of family, genus or species, ${ }^{1}$ and the species Rhipicephalus microplus causes substantial losses for beef and milk cattle due to spoliation of cattle and the high cost of current control techniques. ${ }^{2-4}$ These parasites have a lifecycle in the host and another in the pasture, and only females fill with blood, after they release themselves from the host and fall to the ground, where they seek a dark and humid place, suitable to lay their eggs. ${ }^{5}$ The weather conditions in Brazil contribute to the development of the ectoparasite, allowing ticks populations to be virtually established in the entire country. ${ }^{6}$ The chemical control is currently the preferred for the combat of ticks; however, the incorrect use of this method favors the occurrence of multiple or cross resistance. ${ }^{7,8}$ In addition, the permanence of residues in animals and their products, thereby, alternatives to the control of this parasite are highly relevant. ${ }^{9}$

There are several natural enemies that contribute to the control of this parasite in the host or in the soil, such as fungi, bacteria, vertebrate and invertebrate animals, which have already been identified for use in biological control. ${ }^{10}$ Particularly, fungi show a series of favorable factors that make them an excellent choice for the control of ectoparasites. They are able to affect insects and mites, some are very virulent, and are of broad spectrum, infect different stages of development of the parasites such as eggs, larvae, pupae, nymphs and adults, what are desirable and particular features of the group. ${ }^{11}$

Unlike other micro-organisms, fungi do not need to be ingested by the host for infection. If only they have contact with the target, their conidia can germinate. ${ }^{12}$ The ease of propagation, production in artificial means, dispersal, lack of environmental pollution and toxicity to humans among other bodies, make fungi highly efficient agents for tick's control. ${ }^{13}$ Agribusiness represents one-third of Brazilian gross domestic product (PIB), and in this sense, the cattle raising represents one of the main branches, once Brazil is amidst the largest producers of meat and dairy products. In opposite, one of the main limitations for Brazilian cattle breeding is the economic loss occasioned by ticks. ${ }^{13,9}$

The use of chemicals in sub and overdose, inadequate preparations and applications, beyond other factors, cause ticks do survive after the contact with the product. Once ticks survive a chemical application, these will transfer genetic information to subsequent generations regarding resistance to that product. ${ }^{14}$ The exclusive use of acaricides is each day less feasible in practical and economic terms, making necessary exploring alternative methods for such control systems. ${ }^{15}$ Researches aimed at assessing the potential of entomopathogenic fungi are essential in order to understand the efficiency difference of the isolates and choose the most suitable for its use in tick's biocontrol programs. ${ }^{11}$ Thus the present study aimed to isolate, identify and select efficient strains in the biological control of Rhipicephalus microplus at the tropics.

\section{Methods}

Representative random samples of soil and Brachiaria brizantha were obtained on the premises of the cattle sector of the Federal Goiano Institute (IF Goiano), campus Ceres. The region is located in the State of Goiás, Central-Western Brazil. The sampled area has a 
typical dystrophic red latosoil, cultivated with Brachiaria brizantha. The forager studied was not under animal grazing.

The material sampled was homogenized according to each treatment, for subsequent removal of a subsample of $1 \mathrm{~g}$. The subsamples were added sterile distilled water at a ratio of 1:10 (final volume of $10 \mathrm{~mL}$ ), serially, until $10^{-5}$ dilution was reached. A $1 \mathrm{~mL}$ aliquot was taken from the last dilution, and inoculated into Petri dishes containing Potato Dextrose Agar culture medium (BDA, Difco, USA). The solution was spread-plated with the help of a sterile drigalsky strap. Then, the plates were incubated at $37^{\circ} \mathrm{C}$ for growth and sporulation of fungi, for up to 15 days.

A Metarhizium anisopliae strain (reference fungus in biological control of ticks) was purchased and multiplied in the same means of culture in the laboratory of the IF Goiano, Ceres. We also evaluated strains of Aspergillus spp. from the rumen of cattle reared in extensive grazing system, ceded from the Federal University of Minas Gerais (UFMG). ${ }^{16}$ The colonies developed were quantified (colony forming units-CFU) and a representative of each morpho type was grown in solid media and separated for later manipulation and identification. The identification was based on macroscopic characteristics of the colony, such as color, shape and appearance, as well as microscopic and reproductive structures, through the technique of slide culture. ${ }^{17}$ Metarhizium anisopliae isolates (conidiophores in compact columns; globose elongated or rod-shaped conidia; green colony, green yellow, gray or yellowish white) was also grown in solid media and separated, along with the other obtained fungi and stored in the collection by the technique of Castellani.

Samples of engaged females (soft ticks) of the species Rhipicephalus microplus were collected randomly from cattle of Ceres-GO and brought to our laboratory. Subsequently, each parasite was collected and separated by weight for the bioassay. Each individual represented a repeat. Each fungal strain evaluated consisted in a treatment. Solutions of the fungal isolates obtained were standardized according to the McFarland scale 3 (concentration: $10^{11}$ conidia $\mathrm{mL}^{-1}$ ). The conidia were scraped from the surfaces of the plates containing the fungus and resuspended in sterile distilled water with two to three drops of Tween 20 surfactant. ${ }^{16}$ The control treatment (negative) was represented by sterile distilled water sprinkling in the experimental units.

The female sticks were stored inside petri dishes $(90 \times 90 \times 90 \mathrm{~cm})$ and individually plated with $10 \mu \mathrm{L}$ of a standardized solution for the inoculum of the respective fungi. Each fungus was sprayed in 5 experimental units. After spraying, the boards were incubated at $26^{\circ} \mathrm{C}$ and followed to a $12 \mathrm{~h}$ photo phase. Readings were taken for determining capacity for colonization and antagonism of inocula every five days until the $30^{\text {th }}$ day after the treatment. Dead ticks were quantified by observing the Mycelial growth and conidiogenesis in the surface of the parasites and the rate of colonization was measured qualitatively by visual observation $(-,+,++,+++)$, methodology adapted from Leo et al. After, we determined the mortality rate for each treatment.

We also evaluated the antagonist activity against eggs. We performed the asepsis of the cuticle of the females of R. Microplus, using a $1 \%$ sodium hypochlorite solution, and then we fitted them out at room temperature to obtain eggs. The posture of eggs until the $10^{\text {th }}$ day was weighed on aliquots of $50 \mathrm{mg}$, packed in sealed test tubes with cotton wool and kept in a heated chamber. An aliquot of
$1 \mathrm{~mL}$ of suspensions of fungal spores were added to the tubes, and the eggs were exposed for three minutes. Following, the tubes were reversed so that the excess of suspension was absorbed by the cotton that was sealing the tubes. The groups were incubated at $27 \pm 1^{\circ} \mathrm{C}$ (humidity $\geq 80 \%$ ). The percentage of hatching of each group was evaluated every five days until the $30^{\text {th }}$ day after the treatment. Each isolated obtained was evaluated as the production of mycotoxins as described by Abrão FO et al. ${ }^{16}$

The experimental design was completely randomized, using exploratory analysis for all variables analyzed, in order to verify and normality through the Liliefors and Bartlett tests. Non-parametric variables were compared by Kruscall-wallis test or Mann-Whitney, as need $(p=0.05)$. All analyses were carried out in the statistical package ASSISTAT 7.7 Beta. ${ }^{18}$

\section{Results}

The forage of this study showed the highest CFU.g-1 counting's, and differed statistically from soil samples $(p<0.05)$ (Figure 1). During the experiment we quantified an average of $2.0 \times 103 \mathrm{CFU} \mathrm{g} \mathrm{g}^{-1}$ fungi and identified the genus Aspergillus, Gliocadium, Paecilomyces, Trichoderma, Trichophyton and Scedosporium (Table 1). Regarding the capacity for colonization of females (Table 2), M. anisopliae colonized the parasites with $80 \%$ efficiency, and differed statistically from other treatments $(p<0.01)$. However, the parasite was colonized by other genera such as Aspergillus.

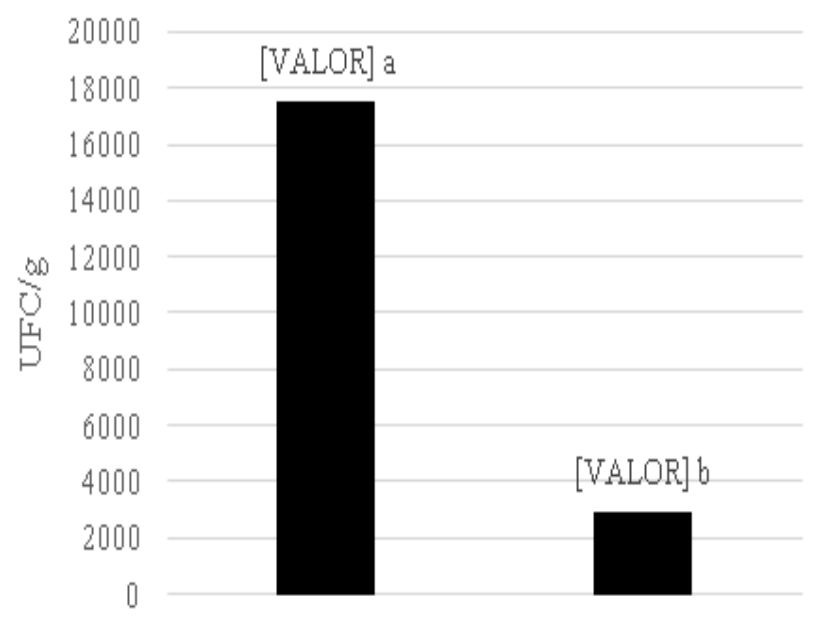

Figure I Number of CFU. $g^{-1}$ in different sampling locations. Medium followed by distinct letters, differ by the Mann-Whitney test a I\% probability.

The colonization of the tick was observed between 48 and $72 \mathrm{~h}$ after infection, being characterized by the presence of fungal structures on the parasite (Figure 2). Shortly after the death of engorged females, the first points of fungus growth externally were observed, as well as the fungal mycelium on the parasites, and the growth reached all the body of the female. The conidiogenesis began between the $8^{\text {th }}$ and $10^{\text {th }}$ days after the infection. The treatment with M. Anisopliae conidia resulted in high production of conidia, what was not observed in other treatments. Regarding the colonization rate of eggs, unexpectedly, we did not notice any antagonist activity. Other studies should be conducted in order to elucidate this observation, once M. Anisopliae was expected to be efficient. Mycotoxin production was observed only in two isolates, Aspergillus spp. (strain S1) and Trichophyton spp. (strain F6). 


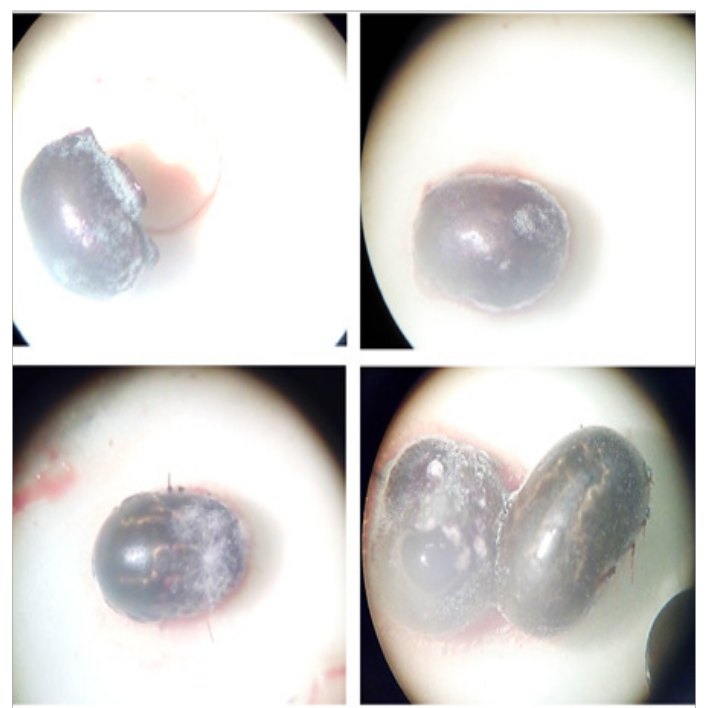

Figure 2 Colonization of engorged females of Rhipicephalus microplus by fungi isolated.
Table I Distribution of the genera of fungi, identified by microculture technique, isolates of Brachiaria brizantha and latosol

\begin{tabular}{lll}
\hline Genera & B.brizantha* & Soil \\
\hline Aspergillus & 5 & 4 \\
Gliocladium & $\mathrm{I}$ & 0 \\
Paecilomyces & $\mathrm{I}$ & 0 \\
Trichoderma & $\mathrm{I}$ & 0 \\
Trichophyton & $\mathrm{I}$ & 0 \\
Scedosporium & 0 & 1 \\
Mycelia Isterina & $\mathrm{I}$ & 0 \\
Total & 10 & 5
\end{tabular}

*Brachiaria brizantha

Table 2 Rate of colonization of engorged females of Rhipicephalus microplus subjected to treatment with their fungal isolates

\begin{tabular}{lllll}
\hline Isolated & Origin & Mass of females (g) & Colonization rate (\%) & Mortality (\%) \\
\hline Metarhizium Anisopliae & Commercial & $\mathrm{I}, 07$ & $80 \mathrm{a} *$ & $80 \mathrm{a}^{*}$ \\
Aspergillus Fumigatus(RI) & Rumen & $\mathrm{I}, 03$ & $4 \mathrm{~b}$ & $60 \mathrm{~b}$ \\
Aspergillus spp.(FI) & Forage & $\mathrm{I}, 02$ & $20 \mathrm{~b}$ & $20 \mathrm{~b}$ \\
Aspergillus spp.(SI) & Latosol & $\mathrm{I}, 04$ & $7 \mathrm{~b}$ & $60 \mathrm{~b}$ \\
Aspergillus Terreus(S2) & Latosol & $\mathrm{I}, 04$ & $20 \mathrm{~b}$ & $40 \mathrm{~b}$ \\
Aspergillus spp.(F2) & Forage & $\mathrm{I}, 02$ & $7 \mathrm{~b}$ & $20 \mathrm{~b}$ \\
Aspergillus Terreus(F3) & Forage & $\mathrm{I}, 08$ & $0 \mathrm{~b}$ \\
Aspergillus Terreus(R2) & Rumen & $\mathrm{I}, 03$ & $8 \mathrm{~b}$ & $20 \mathrm{~b}$ \\
Aspergillus spp.(S3) & Latosol & $\mathrm{I}, 08$ & $0 \mathrm{~b}$ & $60 \mathrm{~b}$ \\
Trichoderma spp.(F4) & Forage & $\mathrm{I}, 09$ & $6 \mathrm{~b}$ & $0 \mathrm{~b}$ \\
Scedosporium Prolificans (S4) & Latosol & $\mathrm{I}, 08$ & $\mathrm{I}$ b b & $20 \mathrm{~b}$ \\
Aspergillus Terreus(F5) & Forage & $\mathrm{I}, 06$ & $7 \mathrm{~b}$ & $20 \mathrm{~b}$ \\
Trichophyton spp.(F6) & Forage & $\mathrm{I}, 06$ & $0 \mathrm{~b}$ & $0 \mathrm{~b}$ \\
Aspergillus spp.(R3) & Rumen & $\mathrm{I}, 04$ & $0 \mathrm{~b}$ & $0 \mathrm{~b}$ \\
Aspergillus Terreus(F7) & Forage & $\mathrm{I}, 07$ & $0 \mathrm{~b}$ & $0 \mathrm{~b}$ \\
Negative Control & He & $\mathrm{I}, 05$ & $0 \mathrm{~b}$ & $0 \mathrm{~b}$ \\
\hline
\end{tabular}

Averages followed by the same letter in column does not differ statistically by Kruskall-Wallis at $5 \%$ probability. *indicate statistically $(p$ value $=0,05)$ different from the other fungus

\section{Discussion}

Among the factors that may have contributed to the low fungal counting's from soil samples, according to Klich, ${ }^{19}$ include the reduced floristic diversity, abiotic factors and inadequate management of the explored areas. The greatest diversity of fungal genera in forage can be related to the moisture content. ${ }^{20}$ Was observed abundance of fungi in soil-derived material and air that was dead or senescent, developing specifically in native grasses on saproling form. ${ }^{21}$ Considering the presence of saprophytic genera in this environment, authors described that the presence of fungi in forages can be related to parasitism, reflecting diseases or saprophytismon plant. ${ }^{22}$

The correct management of soil and crops may influence the dynamics of populations of soil organisms, and crop rotation, cultivation in coverage, use of manures are practices that supports a the diversity of the population in soils. ${ }^{23}$ Entomopathogenic, pathogenic, saprophytes and keratinophylic species are present in the ecosystems we studied here. In spite of the nutrient poor environment in which they were obtained, we observed a great diversity of fungal organisms, 
including species with potential for showing use in biological control programs, such as Trichoderma spp.

Aspergillus was the most prevalent genus, corroborating with the results obtained by Borges et al. All genera we identified here are commonly found in soil of forests, fields, sandy soils or cultivated areas. ${ }^{24}$ Other studies should be conducted seeking to evaluate other fungi concentrations, forms of manipulation, among other parameters, as it was possible to observe Apergillus spp. strains with significant antagonist activity, although it is not statistically similar to the positive control, suggesting a biologically relevant tendency.

Wasassessed the mechanism of infection by M. Anisopliae in experimental conditions and observed that the fungus is able to invade and colonize $R$. Microplus when viable conidia are sprayed, occurring the penetration of the fungus in the cuticle of the parasite..$^{25}$ In surveys conducted by Kaaya \& Garcia ${ }^{26,27}$ it was described that suspensions of $M$. Anisopliae in high concentrations resulted in considerable reduction in egg hatching rate of engorged female ticks, when compared to the control.

Authors reported the formation as one of the major points of the penetration of entomopathogenic fungi in the tegument of the host, and its formation is associated to the intense metabolism required for the synthesis of exoenzymes involved in the degradation of the cuticle. ${ }^{25}$ We have not noticed the penetration in natural openings of the tick (mouthparts, respiratory spiracles, anal and genital orifices), as described in bugs infected with several species of fungi, corroborating the results found by Garcia. ${ }^{27}$ In a similar study, reported the anal penetration of Aspergillus ochraceus in engorged female tick $R$. Sanguineus. ${ }^{28}$

In this sense the tegument penetration becomes an interesting feature in the choice of fungi that can be explored for the control of arthropods, considering that the sucking mouthparts of the arthropod are inserted in the body of its host, making it not feasible to oral infection. ${ }^{3}$ The time required for germination and penetration in the host is also an important feature for the choice of the strains.

According to Iamanaka ${ }^{29}$ the fungal genera most commonly associated with toxins are Aspergillus, Penicillium and Fusarium, being the first and the last distinguished by contaminated agricultural products and/or foodstuffs, and also for the production of secondary metabolites, mycotoxins, which and may cause harms in humans and animals. $^{30}$

\section{Conclusion}

Under the conditions of this experiment, Aspergillus fungus most prevalent both in the soil and in tropical regions forage. High fungal diversity is observed in the ecosystem. M. Anispliae is the female antagonist engorged of $R$. Microplus, therefore the effective agent in cattle tick biocontrol in tropical regions. In the current study, no other fungus was superior to Metarhizium anisopliae, a reference fungus currently used in biological control of ticks. ${ }^{31-37}$

\section{Acknowledgements}

To the Federal Goiano Institute. The Federal University of Minas Gerais.

\section{Authors' contributions}

JPO and BSP executed the experiment protocol, analyzed the results and drafted the manuscript. MVDS assist in translation and drafted manuscript. FOAP wrote the project and the manuscript and guided the work and statistical analyzes.

\section{Conflict of interest}

Author declares that there is no conflict of interest.

\section{References}

1. Barros-Battesti DM, Arzua M, Bechara GH. Carrapatos de importância médico-veterinária da região neotropical: um guia ilustrado para identificação de espécies. Vox/ICTTD-3/Butantan, São Paulo, Brazil; 2006. p. 223.

2. Basso LMS. Controle de larvas de Boophilus microplus por Metarhizium anisopliae em pastagens infestadas artificialmente. Pesq Agropec Bras. 2005;40(6):595-600.

3. Garcia MV. Aplicação do fungo Metarhizium anisopliae em pastagem visando o controle do carrapato Boophilus microplus em bovinos. Tese (Doutorado). Universidade Estadual Paulista Faculdade De Ciências Agrárias E Veterinárias. Jaboticabal - SP, 58f. 2008.

4. Ramos JAG, Oliveira RR, Bechtlufft MP. Perfil de proteínas de ovo de carrapato Boophilus micropulus. SynThesis Rev Digit FAPAM, Pará de Minas. 2009;1(1):274-281.

5. Veríssimo CJ. Controle biológico do carrapato do boi, Rhipicephalus (Boophilus) microplus no Brasil /Biological control of the cattletick Rhipicephalus (Boophilus) microplus in Brazil. Continuous and Zootech of CRMV-SP. São Paulo: Conselho Regional de Medicina Veterinária. Educ J in Vet Med. 2013;11(1):14-23.

6. Kassab SO. Isolados de fungos entomopatogênicos no controle do Rhipicephalus (Boophilus) microplus (Canestrini, 1887) (Acari: Ixodidae). Rev Verde. Mossoró -RN. 2011;6(3):222-225.

7. Furlong J, Martins JR, Prata MCA. O carrapato dos bovinos e a resistência: temos o que comemorar? A Hora Vet. 2007;27(159):26-32.

8. Rocha CMBM, Paulo Roberto O, Romário Cerqueira L, et al. Percepção dos produtores de leite do município de Passos, MG, sobre o carrapato Boophilus microplus (Acari: Ixodidae). Ciência Rural. 2006;36(4):1235-1242.

9. Amaral MAZ, Christiane Maria BMR, João Luiz F, et al. Perceptions and attitudes among milk producers in Minas Gerais regarding catle tick biology and control. Rev Brasde Parasit Vet Jaboticabal. 2011;20(3):194-201.

10. Veríssimo CJ. Fatores que afetam a fase de vida livre de carrapatos. In: Controle de carrapatos nas pastagens. Continuous Educ $J$ in Vet Med and Zootech of CRMV-SP. Nova Odessa: Instituto de Zootecnia. 2013;11(1):11-26.

11. Barci LAG, José Eduardo MDA, Adriana HDCa, et al. Determinação da CL90 e TL90 do isolado IBCB66 de Beauveria bassiana (Ascomycetes: Clavicipitaceae) para o controle de Rhipicephalus (Boophilus) microplus (Acari: Ixodidae). Rev Brasde Parasit Vet Jaboticabal. 2009;18(1):34-39.

12. Oliveira FR. Prospecção de fungos para o controle de Anticarsia gemmatalis hübner, 1818 (Lepidoptera: Noctuidae) 69f (Dissertação de mestrado). Santa Maria-RS, Brazil: Universidade Federal de Santa Maria, Centro de Ciências Naturais e Exatas Programa de Pós-Graduação em Agrobiologia. 2013.

13. Monterio CMO. Controle de Rhipicephalus microplus (ACARI: IXODIDAE) com nematoides entomopatogênicos: aplicação em formulação inseto cadáver e compatibilidade com outros agentes de controle $198 f$ (Dissertação de doutorado). Seropédica-RJ, Brazil: Universidade Federal Rural do Rio de Janeiro - Instituto de Veterinária Curso de Pós-Graduação em Ciências Veterinárias. 2014. 
14. Furlong J, Prata M. Controle estratégico do carrapato dos bovinos de leite. EMBRAPA, Juiz de Fora, Brazil; 2006. 2p.

15. Nogueira AH. Atividade acaricida do isolado IBCB 425 do fungo Metarhizium anisopliae sobre larvas do carrapato Boophilus microplus (CANESTRINI). Biológic São Paulo. 2006;68(Suppl):199-201.

16. Abrão FO, Duarte ER, Freitas CE, et al. Characterization of fungi from ruminal fluid of beef cattle with different ages and raised in tropical lignified pastures. Curr Microbiol. 2014;69(5):649-659.

17. Kern ME, Blevins KS. Micologia médica-Texto e Atlas. 2nd ed. São Paulo: Editoral Premier; 1999.

18. Silva Fase, Azevedo CAV. Principal Components Analysis in the Software Assistat Statistical Attendance. In: World Congress on Computers in Agriculture, 7. USA: Reno-NVUSA: Anais American Society of Agricultural and Biological Engineer; 2009.

19. Klich MA. Biogeography of Aspergillus species in soil and litter Mycologia. 2002;94(1):21-27.

20. Reis RA. Effects of the ammoniation on the occurrence of fungi, chemical composition, and in vitro digestibility of grama seda (Cynodon dactylon (L.) Pers.) hays. Rev Bras de Zootec. 1997;26(3):454-460.

21. Lacey J. Potential hazards to animal and man from microorganisms in fodders and grain. Transact of the British Mycol Society. $1975 ; 65(2): 171-184$

22. Nepomuceno DD. Associação de fungos a cinco espécies de leguminosas forrageiras. In: Encontro Latino Americano De Iniciação Científica E Encontro Latino Americano De Pós-Graduação. São José dos Campos, SP. Anais... São José dos Campos: Universidade do Vale do Paraíba, Brazil; 2008:1-3.

23. Gliessmann SR. Agroecologia: processos ecológicos em agricultura sustentável. Porto Alegre, Brazil: Editora Universidade; 2000.

24. Stamford NP. Microbiota dos solos tropicais. In: Michereff SJ, editor Ecologia e manejo de patógenos radiculares emsolos tropicais. Recife: UFRPE, Imprensa Universitária, Brazil; 2005:61-92 p.

25. Bittencourt VREP, Mascarenhas AG, Faccini JLH. Mecanismo de infecção do fungo Metarhiziumanisopliae no carrapato Boophilusmicroplus em condições experimentais. Ciência Rural. 1999;29(2):351-354.

26. Kaaya GP, Hassan S. Entomogenous fungi as promising biopesticides for tick control. Exp Appl Acarol. 2000;24(12):913-926.
27. Garcia MV, Monteiro AC, Szabó MPJ. Mechanism of infection and colonization of Rhipicephalus sanguineus eggs by Metarhizium anisopliae as revealed by scanning eletron microscopy and histopathology. Braz $J$ Microbiol. 2005;36(4):368-372.

28. Estrada-Penã A, Jongejan F. Ticks feeding on humans: a review of records on human-biting Ixodoidea with special reference to pathogen transmission. Exp Appl Acarol. 1999;23(9):685-715.

29. Iamanaka BT, Oliveira IS, Taniwaki MH. Micotoxinas em Alimentos. Recife, Brazil: Anais da Acad Pernamb de Ciência Agron; 2010;7:138-161.

30. Lazzari FA. Umidade, fungos e micotoxinas na qualidade de sementes, grãos e rações. Curitiba, Brazil; 1997.

31. Camargo MG, SÁ FA, Kluck GEG. Interação entre Scopulariopsis brevicaulis, Metarhizium anisopliae e Rhipicephalus microplus em condições de laboratório. Rev Bras de Med Vet. 2012;34(Suppl 1):60-65.

32. Farias NA, Ruas JL, Santos TRB. Análise da eficácia de acaricidas sobre o carrapato Boophilus microplus, durante a última década. na região sul do Rio Grande do Sul. Ciencia Rural. 2008;38(6):1700-1704.

33. Garcia MV, Monteiro AC, Szabo MPJ. Colonização e lesão em fêmeas ingurgitadas do carrapato Rhipicephaluss anguineus causadas pelo fungo Metarhizium anisopliae. Santa Maria: Ciência Rural. 2004;34(5):1513-1518

34. Monteiro GG. Análise da comunidade de fungos em solos da Amazônia por eletroforese em gel com gradiente desnaturante (DGGE). Lavras: UFLA, Brazil; 2007. 48p

35. Saito M, Machida S. A rapid identification method for aflatoxin producing strains of Aspergillus flavus and A. parasiticus by ammonia vapor. Mycoscience. 1999;40(2):205-208.

36. Silva EEC. Carrapato de Bovinos Rhipicephalus (Boophilus) microplus, canestrini, 1888 (Acari: ixodidae) e sua sensibilidade a solventes. In: Tópicos especiais em Ciência Animal III - Alegre, CAUFES, ES, Brazil; 2014. p. 185-195.

37. Wallis PD, Haynes RJ, Hunter CH, et al. Effect of land use and management on soil bacterial biodiversity as measured by PCR-DGGE, Netherlands. Appl Soil Ecol. 2010;46(1):147-150. 